\title{
HUBUNGAN KEBIASAAN MEMBACA DENGAN PENURUNAN KETAJAMAN PENGLIHATAN ANAK SEKOLAH DI SD SANTO ANTONIUS 02 BANYUMANIK SEMARANG
}

\author{
Ahmad Fahrur Rozi, Rosalina, Dwi Novitasari \\ Program Studi Keperawatan STIKES Ngudi Waluyo
}

\begin{abstract}
ABSTRAK
Penurunan tajam penglihatan pada anak usia sekolah merupakan masalah kesehatan yang penting. Kelainan refraksi biasa disebabkan oleh adanya faktor kebiasaan membaca terlalu dekat, pencahayaan, durasi, posisi sehingga menyebabkan kelelahan pada mata. Penelitian ini bertujuan untuk Mengetahui hubungan kebiasaan membaca dengan ketajaman penglihatan pada anak usia sekolah SD Santo antonius Banyumanik, Semarang.

Metode penelitian yang digunakan dalam penelitian ini adalah Penelitian case control atau kasus control. Penelitian telah dilakukan di SD Santo Antonius Banyumanik, Semarang pada agustus 2015 dengan jumlah popolasi 490 dengan mengunakan teknik Sampling Purposive di dapatkan sampel 84 responden Alat pengambilan data menggunakan kartu snellen dan kuesioner. Analisa data yang digunakan adalah Chi Square .

Hasil uji Chi Square didapatkan $p$ value $0,047 \leq 0,05$ sehingga ada hubungan yang signifikan antara Kebiasaan Membaca Dengan Penurunan Ketajaman Penglihatan di SD Santo Antonius 02 Banyumanik Semarang.

Berdasarkan hasil penelitian diharapkan siswa siswi SD Santo Antonius 02 Banyumanik Semarang mengubah kebiasaan membacanya yang salah menjadi benar dan berkurang angka kejadian anak mengalami penurunan ketajaman penglihatan.
\end{abstract}

\section{Kata kunci : kebiasaan membaca dan penurunan ketajaman penglihatan}




\begin{abstract}
Decrease in visual acuity in children of school age is, important health problem. Ordinary refractive disorders caused by factors habit of reading too closely, lighting, duration, position, causing eyestrain. This study aims at knowing the relationship with the reading habits of visual acuity in children of school age Santo antonius Banyumanik, Semarang.

The method used in this study is a case-control study or case control. Research has been conducted in elementary school St. Anthony Banyumanik, Semarang in August 2015 the number of popolasi 490 by using purposive sampling technique in getting samples of 84 respondents used the card data retrieval tool Snellen and questionnaires. Analysis of the data used is Chi Square.

Chi Square test results obtained $p$ value $0,047 \leq 0,05$ so that there is a significant correlation between Reading Habits With the decline in sharpness of vision at Santo Antonius 02 Banyumanik Semarang.

Based on the results of the study are expected to elementary school students of Santo Antonius 02 Banyumanik Semarang change the habit of reading it wrong to be right, and reduced the incidence of child decreased visual acuity.
\end{abstract}

\title{
Keywords : reading habits and decreased vision acuity
}




\section{PENDAHULUAN}

Visus mata (ketajaman penglihatan) merupakan kemampuan sistem penglihatan untuk membedakan berbagai bentuk (Anderson, 2007). Penglihatan yang optimal hanya dapat dicapai bila terdapat suatu jalur saraf visual yang utuh, mata yang sehat serta kemampuan fokus mata yang tepat (Riordan-Eva, 2007). Prevalensi penurunan pengelihatan terparah penduduk umur 6 tahun keatas secara nasional sebesar 0,9 persen. Prevalensi penurunan pengelihatan terparah yang paling tinggi terdapat di Lampung $(1,7 \%)$, diikuti Nusa Tenggara Timur, Jawa Tengah dan Kalimantan Barat (masing-masing 1,6\%). Provinsi dengan prevalensi penurunan pengelihatan terparah yang paling rendah adalah DI Yogyakarta $(0,3 \%)$ diikuti oleh Papua Barat dan Papua (masing-masing 0,4\%) (Riskesdas, 2013).

Kelelahan mata disebabkan oleh stres yang terjadi pada fungsi penglihatan. Stres pada otot akomodasi dapat terjadi pada saat seseorang berupaya untuk melihat pada objek berukuran kecil dan pada jarak yang dekat dalam waktu yang lama. Pada kondisi demikian, otot-otot mata akan bekerja secara terus menerus dan lebih dipaksakan. Ketegangan otot-otot pengakomodasi (otot-otot siliar) makin besar sehingga terjadi peningkatan asam laktat dan sebagai akibatnya terjadi kelelahan mata, stress pada retina dapat terjadi bila terdapat kontras yang berlebihan dalam lapangan penglihatan dan waktu pengamatan yang cukup lama (Ilyas, 2010). Kebiasaan membaca adalah kegiatan membaca yang telah mendarah daging pada diri seseorang (dari segi kemasyarakatan, kebisaan adalah kegiatan membaca yang telah membudaya dalam suatu masarakat).

Dampak Kebiasaan membaca
Terhadap penurunan ketajaman pengelihatan kelelahan mata timbul sebagai stres intensif pada fungsi-fungsi mata seperti terhadap otot-otot akomodasi pada pekerjaan yang perlu pengamatan secara teliti atau terhadap retina sebagai akibat ketidaktepatan kontras (Suma'mur, 2006).

\section{Perumusan Masalah Penalitian} Berdasarkan uraian latar belakang di atas, maka peneliti merumuskan masalah penelitian sebagai berikut : “ Apakah ada Hubungan kebiasaan membaca dengan penurunan ketajaman penglihatan pada anak usia sekolah di SD Santoantonius Banyumanik, Semarang

Tujuan penelitian Mengetahui hubungan kebiasaan membaca dengan ketajaman penglihatan pada anak usia sekolah SD Santoantonius Banyumanik, Kabupaten Semarang.

\section{METODE PENELITIAN}

Penelitian case control atau kasus control adalah suatu penelitian (survei) analitik yang menyangkut bagaimana faktor resiko dipelajari dengan menggunakan pendekatan retrospective. Penelitian telah dilakukan di SD Santo Antonius Banyumanik, Semarang pada 3 Agustus 2015

Populasi dalam penelitian ini adalah anak usia sekolah yang sedang sekolah di SD Santo Antonius 02 Banyumanik, Semarang dengan jumlah yaitu 490 siswa usia sekolah. Sempel dibagi dua kelompok yaitu kelompok kasus dan kelompok kontrol total populasi berjumlah 490 Dari jumlah populasi di dapatkan kelompok kasus dan kontrol 42 responden yang mengalami penurunan penglihatan dan tidak mengalami penurunan penglihatan setiap kelompok kasus maupun kelompok kontrol berjumlah 42 responden sehingga total 84 responden untuk kelompok kasus dan kelompok kontrol, Pengambilan sampel mengunakan teknik sampling purposive. Sebelum melakukan penelitian melakukan proses perizinan kepada kepala sekolah SD Santo Antonius 02 Banyumanik Semarang sehingga dapat melakukan penelitian pada tanggal 3 dan 4 agustus 2015. Saat pada tanggal 3 agustus 2015 saya melakukan penelitian pada kelompok kasus sebelum saya melakukan penelitian saya memberi penjelasan proses penelitian saya kepada anak-anak, sesudah memberi penjelasan saya langsung melakukan pemeriksaan ketajaman penglihatan oleh perawat. 
profesional sejumlah 42 responden untuk kelompok kasus sesudah pemeriksaan langsung dilakukan pengisian kuesioner, untuk kelompok kontrol pada tanggal 4 agustus 2014 dilakukan sama pemeriksaan dan pengisian kuesioner pada kelompok kontrol.

Analisa data Penelitian melakukan analisis univariat dengan tujuan yaitu untuk mendiskripsikan variabel kebiasaan membaca dengan penurunan ketajaman pengelihatan anak usia sekolah yang disajikan dalam bentuk tabel distribusi frekuensi. Analisis bivariat menggunakan chi- square melalui bantuan program komputer.

\section{HASIL PENELITIAN}

\section{A. Univariat}

\section{Kebiasaan Membaca}

Tabel 1 Distribusi Frekuensi Responden Berdasarkan Kebiasaan Membaca di SD Santo Antonis 02 Banyumanik Semarang

\begin{tabular}{lllllll}
\hline $\begin{array}{l}\text { Kebiasaan } \\
\text { membaca }\end{array}$ & kasus & $\%$ & kontrol & $\%$ & total \\
\hline Buruk & 29 & 69,0 & 19 & & 45,2 & 48 \\
Baik & 13 & 31,0 & 23 & & 54,8 & 36 \\
\hline jumlah & 42 & $100,(42$ & & 100,0 & 84 \\
\hline
\end{tabular}

Tabel 1 menunjukkan bahwa kebiasaan membaca buruk untuk kelompok kasus 29 $(69,0 \%)$ sedangkan kebiasaan baik sebanyak $13(31,0 \%)$ untuk kelompok kontrol kebiasaan buruk sebanyak $19 \quad(45,2 \%)$ sedangkan kebiasaan baik 23 anak $(54,8 \%)$.

\section{Pemeriksaan penglihatan \\ ketajaman}

Tabel 2 Distribusi Frekuensi Responden Berdasarkan pemeriksaan

Ketajaman Penglihatan di SD

Santo Antonis 02 Banyumanik Semarang

\begin{tabular}{lllllll}
\hline \multirow{2}{*}{$\begin{array}{c}\text { Hasil } \\
\text { visus }\end{array}$} & \multicolumn{4}{c}{ kelompok } & \multicolumn{3}{c}{ total } \\
\cline { 2 - 7 } mata & kasus & \multicolumn{3}{c}{ Kontrol } & & \\
\hline $20 / 15$ & 0 & 0 & 14 & 33,3 & 14 & 16,7 \\
$20 / 20$ & 0 & 0 & 28 & 66,7 & 28 & 33,3 \\
$20 / 25$ & 1 & 2,4 & 0 & 0 & 1 & 1,2 \\
$20 / 30$ & 13 & 31,0 & 0 & 0 & 13 & 15,5 \\
$20 / 40$ & 16 & 38,1 & 0 & 0 & 16 & 19,0 \\
$20 / 50$ & 9 & 21,4 & 0 & 0 & 9 & 10,7 \\
$20 / 60$ & 1 & 2,4 & 0 & 0 & 1 & 1,2 \\
$20 / 80$ & 2 & 4,8 & 0 & 0 & 2 & 2,4 \\
total & 42 & 100,0 & 42 & 100,0 & 84 & 100,0 \\
\hline
\end{tabular}

Tabel 2 menunjukkan bahwa hasil visus mata responden yang tinggi dari pemeriksaan visus mata untuk kelompok kasus di dapatkan 20/40 untuk kelompok kasus sebanyak 16 $(31,0 \%)$ untuk vius 20/40 sebanyak 16 $(38,1 \%)$ visus $20 / 50$ sebanyak $9(21,4 \%)$ visus 20/60 sebanyak $1(2,4 \%)$ visus $20 / 80$ sebanyak $2(4,8 \%)$ untuk kelompok kontrol tidak ada yang mengalami penurunan penglihatan hasil visus menunjukan 20/15 dan $20 / 20$.

\section{B. Bivariat}

Tabel 3 "Hubungan Kebiasaan Membaca Dengan Penurunan Ketajaman Penglihatan di SD Santo Antonius 02 Banyumanik Semarang"

\begin{tabular}{|c|c|c|c|c|c|c|c|c|}
\hline \multirow{3}{*}{$\begin{array}{l}\text { Kebiasa } \\
\text { an } \\
\text { memba } \\
\text { ca }\end{array}$} & \multicolumn{2}{|c|}{$\begin{array}{l}\text { Penurunan } \\
\text { penglihatan }\end{array}$} & \multicolumn{2}{|c|}{ ketajaman } & \multicolumn{2}{|c|}{ total } & \multirow[t]{2}{*}{$\begin{array}{l}P \\
\text { value }\end{array}$} & \multirow[t]{2}{*}{$\begin{array}{l}\mathrm{O} \\
\mathrm{R}\end{array}$} \\
\hline & kast & & kor & & & & & \\
\hline & $\mathrm{f}$ & $\%$ & $\mathrm{f}$ & $\%$ & $\mathrm{f}$ & $\%$ & & \\
\hline Buruk & 29 & $\begin{array}{l}69, \\
0\end{array}$ & 19 & 45,2 & 48 & 57,1 & 0,047 & 2,70 \\
\hline Baik & 13 & $\begin{array}{l}31, \\
0\end{array}$ & 23 & 54,8 & 36 & 42,9 & & \\
\hline jumlah & 42 & 100 & 42 & 100 & 84 & 100 & & \\
\hline
\end{tabular}

Tabel 3 dapat diketahui bahwa persentase responden yang mengalami 


\section{JGK-vol.7, no.16 Oktober 2015}

penurunan ketajaman penglihatan dan mempunyai kebiasaan membaca yang buruk $(57,1 \%)$ lebih besar daripada persentase responden yang mengalami penurunan ketajaman penglihatan dan mempunyai kebiasaan membaca yang baik $(42,9 \%)$.

\section{PEMBAHASAN}

\section{A. Gambaran Kebiasaan Membaca}

Hasil penelitian kepada 84 responden, didapatkan bahwa rata-rata kebiasaan membaca pada anak usia sekolah di SD Santo Antonius 02 Banyumanik Semarang, sebesar 48 anak $(57,1 \%)$ memiliki kebiasaan buruk sedangkan yang memiliki kebiasaaan baik 36 anak $(42,9 \%)$ dan yang paling banyak ketegori buruk sebanyak 48 responden. Jumlah kuesoner yang saya berikan kepada responden sebanyak 84 kuesoner didapatkan $23(20 \%)$ responden menjawab benar dan 61 $(70 \%)$ responden menjawab salah. Hasil penelitian menunjukkan bahwa anak usia sekolah yang memiliki kebiasaan membaca, rata-rata yang dibutuhkan lebih dari 2 jam/ hari lebih tanpa dijeda istirahat sehingga mata mengalami kelelahan. Kelelahan adalah suatu mekanisme perlindungan tubuh agar tubuh terhindar dari kerusakan lebih lanjut sehingga terjadi pemulihan setelah istirahat. Kelelahan diatur secara sentral oleh otak, secara umum gejala kelelahan dapat dimulai dari yang sangat ringan sampai perasaan yang sangat melelahkan (Tarwaka, 2004).

Kebiasaan membaca pada anak sekolah yang buruk disebabkan banyak faktor yaitu anak sekolah sering membaca dengan posisi tiduran sebanyak $16(10 \%)$ anak menjawab dengan tiduran. Posisi membaca buku tiduran adalah kebiasaan yang menyenangkan. kebiasaan ini memerlukan perhatian khusus karena cukup berisiko, Posisi ini akan menyebabkan mata mudah lelah. Ini membuat jarak buku dengan mata semakin dekat. Saat berbaring, tubuh tidak bisa relaks karena otot mata akan menarik bola mata ke arah bawah, mengikuti letak buku yang sedang dibaca.

Mata yang sering terakomodasi dalam waktu lama akan cepat menurunkan kemampuan melihat jauh, sehingga dalam ruangan perlu diciptakan lingkungan yang nyaman bagi mata (Hadisudjono, 2007). Sebanyak 50 (59\%) anak dalam kuesioner menjawab cukup dan nyaman untuk pencahayaannya sedangkan $34(40 \%)$ anak menjawab lingkungannya pencahayaannya redup dan terang kurangnya memperhatikan pencahayaan di rumah maupun disekolah jika membaca pada kondisi redup maka akan membuat mata semakin keras untuk berokomodasi akan membuat mata lelah dan sebaliknya jika membaca dengan pencahayaan terang. Maka dari itu harus selalu memperhatikan anak ketika membaca agar terhindar dengan penurunan penglihatan dini. Pheasant (2005).

Posisi mata terhadap obyek yang kecil dan dekat penting untuk diperhatikan. hasil kuesioner jarak membaca $30 \mathrm{~cm}$ sebanyak 51 $(60 \%)$ anak sedangkan yang membaca dengan jarak lebih atau kurang dari 30 sebanyak 33 (39\%) anak. Pandangan mata terhadap obyek yang terlalu dekat dan terus menerus lebih dari dua jam dapat menyebabkan kelelahan mata terutama didalam ruangan yang penerangannya kurang dari 200 lux (Mangoenprasedjo, 2005).

\section{B. Gambaran Penurunan Ketajaman Penglihatan (visus mata)}

Berdasarkan hasil penelitian di atas bahwa anak usia sekolah yang kebiasaan membaca di SD Santo Antonius 02 Banyumanik Semarang (kelompok kasus) sebanyak 42 responden $(50,0 \%)$ yang mengalami penurunan pengelihatan dan pada (kelompok kontrol) yang tidak mengalami penurunan ketajaman penglihatan sebanyak 42 responden $(50,0 \%)$ dari total kelompok kasus dan kelompok kontrol sebanyak 84 responden $(100,0 \%)$. Visus mata (ketajaman penglihatan)

merupakan kemampuan sistem penglihatan untuk membedakan berbagai bentuk (Anderson, 2007). Penglihatan yang optimal hanya dapat dicapai bila terdapat suatu jalur saraf visual yang utuh, stuktur mata yang sehat serta kemampuan fokus mata yang tepat (Riordan-Eva, 2007). 


\section{Hubungan kebiasaan membaca dengan penurunan ketajaman penglihatan pada anak usia sekolah di SD Santo Antonius 02 Banyumanik Semarang}

Berdasarkan hasil analisis data dari penelitian di SD Santo Antonius 02 Banyumanik Semarang, didapatkan data dari mengalami penurunan ketajaman penglihatan dan mempunyai kebiasaan membaca yang buruk $(57,1 \%)$ lebih besar daripada persentase responden yang mengalami penurunan ketajaman penglihatan dan mempunyai kebiasaan membaca yang baik $(42,9 \%)$. Hasil uji Chi Square didapatkan $p$ value 0,047 $\leq 0,05$ sehingga ada hubungan yang signifikan antara kebiasaan membaca dengan penurunan ketajaman penglihatan di SD Santo Antonius 02 Banyumanik Semarang.

Kebiasaan membaca dengan durasi yang cukup lama akan membuat mata lelah dan membuat mata merah, gangguan mata lainnya, dan masalah visual lainya yang timbul seperti gangguan sakit kepala dan sakit leher atau bahu. Selain itu kecendrungan membaca di dalam ruangan akan memicu kerja mata untuk melihat sangat dekat, misalnya ketika membaca menggunakan buku maupun media elektronik. Gangguan pada mata disebabkan adanya kejadian berulang yang menyebabkan bayangan tidak jatuh pada retina sehingga mengakibatkan seseorang mengalami penurunan ketajaman penglihatan. Menurut Pheasant (2005), kemudahan seseorang untuk melihat suatu obyek kerja di lingkungan sangat dipengaruhi oleh beberapa faktor, antara lain Tingkat Pencahayaan (Illumination Levels), Bentuk Obyek Kerja, Kekontrasan, Durasi (Lama Waktu) untuk Melihat Obyek Kerja, Jarak Melihat Obyek Kerja. Maka berlama-lama menatap buku akan berdampak pada kesehatan mata khususnya penurunan visus mata. Hal ini sesuai dengan penelitian yang dilakukan oleh Nourmayanti (2010) dalam penelitiannya mengatakan bahwa tingkat pencahayaan dapat mempengaruhi kelelahan mata yang salah satunya adalah penurunan ketajaman penglihatan.
Gangguan pada mata disebabkan adanya kejadian berulang yang menyebabkan bayangan tidak jatuh pada retina sehingga mengakibatkan seseorang mengalami penurunan ketajaman penglihatan. Apabila seseorang berada di tempat yang sangat terang untuk waktu yang lama, maka banyak sekali fotokimiawi yang terdapat didalam sel batang dan sel kerucut diubah menjadi retinal dan opsin. Selanjutnya sebagian

besar retinal dalam sel batang dan sel kerucut akan banyak berkurang, akibatnya sensitivitas terhadap cahaya juga turut berkurang (Guyton \& Hall, 2006). Dampak membaca terhadap kelelahan mata timbul sebagai stres intensif pada fungsi-fungsi mata seperti terhadap otot-otot akomodasi pada pekerjaan yang perlu pengamatan secara teliti atau terhadap retina sebagai akibat ketidaktepatan kontras. menurut Suma'mur (2006

Menurut Ilyas (2010), kelelahan mata disebabkan oleh stres yang terjadi pada fungsi penglihatan. Stres pada otot akomodasi dapat terjadi pada saat seseorang berupaya untuk melihat pada obyek berukuran kecil dan pada jarak yang dekat dalam waktu yang lama. pada kondisi demikian, otot-otot mata akan bekerja secara terus menerus dan lebih dipaksakan. Ketegangan otot-otot pengakomodasi (otot-otot siliar) makin besar sehingga terjadi peningkatan asam laktat dan sebagai akibatnya terjadi kelelahan mata, stress pada retina dapat terjadi bila terdapat kontras yang berlebihan dalam lapangan penglihatan dan waktu pengamatan yang cukup lama. 


\section{KESIMPULAN}

1. kebiasaan membaca buruk untuk kelompok kasus 29 (69,0\%) sedangkan kebiasaan baik sebanyak $13(31,0 \%)$ untuk kelompok kontrol kebiasaan buruk sebanyak 19 (45,2\%) sedangkan kebiasaan baik 23 anak $(54,8 \%)$.

2. hasil visus mata responden yang tinggi dari pemeriksaan visus mata untuk kelompok kasus di dapatkan 20/40 untuk kelompok kasus sebanyak 16 $(31,0 \%)$ untuk vius 20/40 sebanyak 16 $(38,1 \%)$ visus $20 / 50$ sebanyak 9 $(21,4 \%)$ visus $20 / 60$ sebanyak $1(2,4 \%)$ visus $20 / 80$ sebanyak $2(4,8 \%)$ untuk kelompok kontrol tidak ada yang mengalami penurunan penglihatan hasil visus menunjukan 20/15 dan 20/20 .

3. Ada hubungan yang signifikan antara kebiasaan membaca dengan penurunan ketajaman penglihatan pada anak usia sekolah di SD Santo Antonius 02 Banyumanik Semarang. $p$ value 0,047

\section{DAFTAR PUSTAKA}

Departemen Kesehatan RI. (2009). Upaya Kesehatan Kerja Sektor Informal di Indonesia. Jakarta : Departemen Kesehatan.

Fachrian Dedy, dkk. (2009). Prevalensi Kelainan Ketajaman Penglihatan pada Pelajar SD “ $X$ ” Jatinegara Jakarta Timur. Jakarta; Majalah Kedokteran Indonesia

Ganong, William F. (2005). Fisiologi Kedokteran, diterjemahkan oleh H.M. Djauhari E. Edisi 9. Jakarta: buku kedokteran EGC.

Gondhowiardjo, T.D. (2009). Pengaruh Bermain Komputer Pada Kesehatan Mata Anak-Anak. Jakarta : Ilmu Penyakit Mata RS. Cipto Mangunkusumo.

Guyton \& Hall. (2006). Fisiologi Kedokteran II. Jakarta : EGC.

Wong, D. L. (2008). Buku Ajar Keperawatan Pediatrik. Jakarta: EGC.
WHO. (2009). Deskription And Classification Of Visual Display Terminal In VDT And Woker's Health, Genewa, WHO Ofsset Publication, p. 99.

Riskesdas.(2013). Riset Kesehatan Dasar tahun 2013. Jakarta: Badan Penelitian Pengembangan Kesehatan Kementrian Kesehatan RI.

Wijaya, M. 2010. Prevalensi Penurunan Ketajaman Penglihatan Pada SiswaSiswi Sekolah Dasar Kelas 4-6. (online) (http://repository.usu.ac.id/bitstream/ 123456789/21449/appendix.pdf) diakses 21 september 2014.

Pheasant, (2005). Ergonomics, Works, and Health. USA: Aspen Publisher Inc.

Sugihartati, rahma. 2010. Membaca, gaya hidup dan capitalisme. Yogyakarta: graham ilmu.

Ilyas, H . 2010. Ilmu Penyakit Mata. Badan Penerbit FKUI. Jakarta.

Hurlock, EB. (2008). Psikologi Perkembangan Suatu Pendekatan Sepanjang Rentang Kehidupan. Jakarta: Airlangga.

Dewi, M. (2011). Pengaruh Kebiasaan Anak dalam Bermain game dan membaca pada Komputer terhadap Kesehatan Mata. KTI : SMA Negeri 1 Jember.

Supriati, F. 2012. Faktor-Faktor Yang Berkaitan Dengan Kelelahan Mata Pada Karyawan Bagian Administrasi Di PT. Indonesia Power UPB. Jurnal Kesehatan Masyarakat UNDIP (online) Volume 1, Nomor 2, Halaman 720-730 (http://ejournals1.undip.ac.id/index.p $\mathrm{hp} / \mathrm{jkm}$ ) diakses 12 september 2014.

Burns, P.C,. Betty, D. dan Ross, E.P.2005. Teaching reading in today's elementary schools. Chicago: rand mc. Nally college publishing company. 
Kairupan, T. 2012. Hubungan Antara Aktivitas Fisik Dan Screen Time Dengan Status Gizi Pada Siswa Siswa SMP Kristen Eben Haezar 2. (Tesis) : Universitas Sam Ratulangi Program Pasca Sarjana Program Studi IKM.

Supartini, y. (2004). Buku ajar konsep dasar keperawatan anak.Jakarta: EGC

Masidah, s. (2006). Perkembangan anak usia pra sekolah materi disempurnakan pada pelatihan trening for trainer (TFT) tingkat maksimal lembaga pendidikan pra sekolah

Gunarsa, S.D. (2006). Psikologis Praktis : Anak, Remaja dan Keluarga. Jakarta : PT BPK Gunung Mulia.

Pheasant, Stephen. (2005). Ergonomics, Works, and Health. USA: Aspen Publisher Inc.

Piaget. (2005). Psychology Themes and Variations. USA: Wadsworth.

Erickson. (2007). Developmental Psychology. USA: Wadsworth

Riodan-Eva. (2007). General Ophtalmology. USA: The Mc GrawHill Companies.

Leat. (2009). Assessing Children's Vision: A Handbook. (Online), (http://repository.usu.ac.id/bitstream/ 123456789/21449/4/Chapter\%20II.p df), diaskes November 2014.

Tampubolon, DP.2005. kemampuan membaca: teknik membaca efektif dan efisiensi. Bandung : angkasa.

Crawley dan mauntain, 2007. Strategies for guiding content reading.

Boston : allyn and bacon

Shafi'ie, 2006, burns dkk.,2005. Pengajaran membaca di kelas-kelas awal sekolah dasar. Jakarta: depdikbud.

Lamb dan Arnold (2005), Faktor-faktor yang memengaruhi kemampuan membaca. Jakarta: depdikbud.
Eanes, 2008. Content area literacy: teaching for today and tomorrow. Bonn: dermar publishers, ITP An international thomoson publising company.

Prastiti (2007: 20). Jenis-jenis Membaca . Jakarta: depdikbud.

Tarigan, H.G. 2008. Membaca sebagai suatu keterampilan berbahasa. Bandung: ikip- STIA

Suma'mur, PK. (2006). Higiene Perusahaan Dan Kesehatan Kerja. Jakarta : Sagung Seto.

Heany. (2009). Tinjauan Faktor Pencahayaan Terhadap Kelelahan Mata di Departemen Develovepment PT Hardaya Aneka Shoes Industri Tanggerang Tahun 2001. Depok: Unversitas Indonesia.

Arianti Melita, 2013. Hubungan Antara Riwayat Miopia Di Keluarga Dan Lama Aktivitas Jarak Dekat Dengan Miopia Pspd Untan. http://www.jurnal.untan.ac.id/index.p hp/j fk/article/view/3768/3770

Sasraningrat, Muhammmad Ihsan. 2011. Gambaran Tingkat Pengetahuan dan Sikap Siswa SD Islam Rumaha Cireundeu Kelas 5 dan 6 Terhadap Miopia dan Faktor Yang Mempengaruhinya Tahun 2011. http://perpus.fkik.uinnjkt.ac.id/file_ digital/1.RISET\%20Muhammad\%20 Ihsa n\%20Sasraningrat.pdf Supartoto, 2013. Anak Perempuan Di Yogyakarta Lebih Banyak Menderita Miopi.

http://www.ugm.ac.id/id/post/page? id $=622$

Guyton \& Hall. (2006). Fisiologi Kedokteran II. Jakarta : EGC.

Notoadmodjo, S. (2010). Metodologi Penelitian Kesehatan. Jakarta : Rineka Cipta.

Sugiyono. (2012). Statistika untuk penelitian. Bandung: Penerbit Alfabeta.

Arikunto. (2006). Metodologi Penelitian Suatu Pendekatan Praktek edisi 5. Jakarta: Renika Cipta 